Winter 2009

\title{
A Framework for Understanding Accountability of International NGOs and Global Good Governance
}

\author{
Michael Szporluk \\ Harvard University
}

Follow this and additional works at: https://www.repository.law.indiana.edu/ijgls

Part of the International Law Commons, and the Law and Politics Commons

\section{Recommended Citation}

Szporluk, Michael (2009) "A Framework for Understanding Accountability of International NGOs and Global Good Governance," Indiana Journal of Global Legal Studies: Vol. 16 : Iss. 1 , Article 13.

Available at: https://www.repository.law.indiana.edu/ijgls/vol16/iss1/13

This Symposium is brought to you for free and open access by the Law School Journals at Digital Repository @ Maurer Law. It has been accepted for inclusion in Indiana Journal of Global Legal Studies by an authorized editor of Digital Repository @ Maurer Law. For more information, please contact rvaughan@indiana.edu.

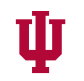

JEROME HALL LAW LIBRARY

INDIANA UNIVERSITY

Maurer School of Law
Blooming ton 


\title{
A Framework for Understanding Accountability of International NGOs and Global Good Governance
}

\author{
Michael Szporluk*
}

\begin{abstract}
International non-governmental organizations (INGOs) promote good governance through global advocacy and through relief and development work. This article focuses on the latter role. While there are legitimate criticisms of INGOs' lack of accountability, this article argues that a review of the different stakeholders in the relief and development sector and their relationships with one another reveals valuable information about what accountability means and to whom stakeholders should be accountable. The article posits that INGOs should be accountable, above all, to the communities where they are implementing projects. Finally, the article points to many efforts being undertaken by INGOs to improve their accountability to communities but asserts that INGOs' efforts would be significantly enhanced if other stakeholders, including donor governments and intergovernmental, organizations addressed their own accountability to communities as well.
\end{abstract}

\section{INTRODUCTION}

One of the major criticisms of international non-governmental organizations (INGOs) ${ }^{1}$ and local civil society organizations (CSOs) has been that they are insufficiently accountable. Indeed, even the title of this conference panel, "Civil So-

* M.P.P., Harvard University. Program Officer, Disability Rights Fund. The author has also worked for Mercy Corps and the Office of the Prosecutor at the International Criminal Tribunal for the former Yugoslavia. The author thanks Angela Garcia for her valuable suggestions.

1. There are many types of INGOs ranging in terms of size, type of engagement (such as emergency relief, sponsorship, service delivery, capacity building, advocacy, multi-purpose), affiliation (such as faith-based or secular), and management structure. In this article, INGO describes the larger multi-purpose organizations that dominate the sector.

Indiana Journal of Global Legal Studies Vol. $16 \# 1$ (Winter 2009)

OIndiana University Maurer School of Law - Bloomington 
ciety: The Answer or the Obstacle to Implementation [of Globalization]" 2 reveals some of the skepticism from those outside the field toward the work of humanitarian and development INGOs.

Unlike their counterparts in the private and public sectors, INGOs and CSOs do not have shareholders and are not elected. ${ }^{3}$ Moreover, in the case of INGOs, most of their work takes place outside their country of origin. ${ }^{4}$ While INGOs obtain funds from various sources (private fundraising through the Internet, intergovernmental organizations, ${ }^{5}$ or country donors), those funds do not require activities undertaken by INGOs to be approved by the communities in which they work. ${ }^{6}$ The individual communities in the "Global South" have little or no influence over which INGO works there and on what sort of project. Thus, there is good reason for caution.

This article will highlight the challenges faced by INGOs and some of their efforts to improve their own accountability. It should be understood, however, that INGOs are only one stakeholder in the larger system of relief and development. This becomes more apparent when one develops a map of the different "accountability relationships." Before that, however, I will do two things. First, I

2. INGOs contribute to globalization of civil society through monitoring of and advocacy at intergovernmental organizations, as well as through their relief and development work in the field. This article focuses on the latter contribution.

3. INGOs and CSOs operate as nonprofit organizations-in the United States under Internal Revenue Code $\S 501$ (c)(3) - and must reinvest any profit back into the organization in furtherance of its mission. INGOS and CSOs are formed voluntarily according to shared interests and goals, and thus their leaders are not elected by community members. Instead, they are accountable to their boards. See National Council of Nonprofit Associations, http://www.ncna.org/ (last visited Sept. 27,2008), for general information on nonprofits in the United States; see International Council of Voluntary Agencies, http://www.icva.ch (last visited Sept. 27, 2008), for general information about international nonprofits.

4. While the largest INGOs are based in the United States and Western Europe, the vast majority of their funds are for project work abroad. Save the Children, for example, spends $7 \%$ of its funds on programming work in the United States. See SAVE THE CHILdREN, Rewriting the FuTURE FOR CHILDREN: ANNUAL REPORT 35 (2007), available at http://ww w.savethechildren.org/pu blications/annual-reports/Save_the_Children_Annual_Report-_web_2-14-08.pdf.

5. Intergovernmental organizations include any organization that has governments as members, such as the United Nations, the World Bank, the International Monetary Fund, the European Commission, and others.

6. An INGO that wins a grant award from a donor must demonstrate knowledge of the country or region where it intends to implement its project and must be legally registered where it works. However, an INGO does not need approval from community leaders or local elected officials to operate. See, e.g., Jem Bendell, Debating NGO Accountability 10 (2006).

7. Most relief and development work occurs in areas known by the terms "developing countries" or "third-world countries." Because these terms are very disrespectful, I use the more neutral term "Global South," despite the fact that not all work occurs in the Southern Hemisphere. 
will review what is meant by the term "accountability." Second, I will examine closely the different actors in the relief and development sector (those who have a stake in global good governance) and compare the resources (both material and soft power) each actor can bring to bear.

\section{Thinking About Accountability}

Michael Edwards and David Hulme write of the related trends during the 1980s and 1990s of increased funding for development and the growing dependency of INGOs and CSOs on governments. ${ }^{8}$ This dependency can cause INGOs and CSOs to steer away from their missions and shift their understanding of accountability away from the communities in which they work and toward their donors. As Mark Lindenberg and Coralie Bryant observed, "Suffice it to say that the emphasis on accountability to donors can lead NGOs to focus on their immediate projects without examining the broader economic, social, and political realities having an impact on communities."'

Exchanges of best practices have emphasized the need to expand the concept of accountability to more stakeholders. ${ }^{10} \mathrm{~L}$. David Brown and Mark Moore have posited that the relationships among the following four stakeholders are important: donors, beneficiaries or clients, staff, and partners or allies." They consider and reject the principal-agent model, in which one actor would play the role of the principal to whom the INGO is accountable. ${ }^{12}$ Instead, they identify three types of programs INGOs operate--service delivery, capacity building, and policy advocacy-and argue that the type of program the INGO operates will determine which relationship takes on the most significance. ${ }^{13}$ Since the relative importance of the relationships is context-and case-specific, the INGO must review all the relevant legal, moral, ethical, and political claims made on them and make a strategic decision about which claim carries the most weight. ${ }^{14}$

8. See Michael Edwards \& David Hulme, Introduction: NGO Performance and Accountability, in Beyond the Magic Bullet: NGO Performance and Accountability in the Post-Cold War WORLD 1-20 (Michael Edwards \& David Hulme eds., 1996).

9. Mark Lindenberg \& Coralie Bryant, Going Global: Transforming Relief and DevelOPMENT NGOS 220 (2001).

10. Examples of these efforts to share information and develop standard practices are cited later in this paper. See id. at 216, for a graphic representation of these relationships.

11. L. David Brown \& Mark H. Moore, Accountability, Strategy, and International Non-Governmental Organizations, 1-2 (Hauser Ctr. for Nonprofit Org., Working Paper No. 7, 2001).

12. Id. at 5 .

13. Id. at $15-26$.

14. Id. at $6-7$. 
The larger INGOs, which have a multitude of purposes and activities, tend to have broad mission statements that, frankly, can mean anything and everything. ${ }^{15}$ In terms of strategy to fulfill these missions, there is much talk of engineering transitions from relief to development, from dependency to empowerment and independence, from poverty to economic opportunity. ${ }^{16}$ While Brown and Moore are correct in their assertion about the importance of different stakeholders, the primary focus for the accountability of INGOs ought to be the communities because that is where INGOs' work takes place.

In his work Debating NGO Accountability, Jem Bendell clarifies the relational obligations inherent in his term "democratic accountability": "the quality of being accountable to those with less power who are affected by one's actions or decisions, when they in turn exhibit the same accountability, where accountable means both justifying to and being regulated by those to whom one is accountable."'?

Democratic accountability suggests a direct correlation between the possession of resources and the obligations one has toward those who have less. The greater one's resources, the more significant one's obligations. Democratic accountability suggests a dynamic relationship built on interactions or exchanges between individuals in different stations, an on-going process in which the local community members, who have less power and fewer resources, have the ability to require INGOs and other actors to account for their work in and for the good of their community. The community and INGOs together (and not the INGOs alone, as Brown and Moore posit) should have say over what decisions are made and how they are carried out.

Taking Bendell's argument one step further, INGOs, ideally, should not only justify to and be regulated by the community, but should also invite community members to participate in the design, implementation, and evaluation of their work. That involvement ought to occur for reasons of practicality as well as principle. The principle of active participation by the populace in decision making (through voting, engagement, petition, advocacy, protest, and other means) is a cornerstone of democratic governance. As Alexis de Tocqueville observed, the right of association is closely related to the right of liberty, ${ }^{18}$ and democracy is endangered if this right is unprotect-

15. See, e.g., LINDENBERG \& BRYANT, supra note 9, at 14.

16. Id.

17. See BENDELL, supra note 6 , at 5.

18. Alexis de Tocqueville, Democracy in America 220 (Arthur Goldhammer trans., Penguin Classics 2004) (1862) ("The freedom most nature to man, after the freedom to act alone, is the freedom to combine his efforts with those of his fellow man and to act in common. The right of association therefore seems to me by its very nature almost as inalienable as the freedom of the individual."). 
ed. ${ }^{19}$ This right is recognized in the rhetoric of the main actors in the relief and development field. As Ray Jennings from the United States Agency for International Development (USAID) observes, "[p]articipation will then inform, contextualize and define the ultimate goal of these and other necessary institution-building activities and encourage accountability to the publics in intervention environments--not donors and governments."20

More practically, INGOs would improve the quality, efficiency, and impact of their work by learning more about the communities in which they operate and utilizing local knowledge and expertise. They must avoid doing harm by reinforcing existing communal power structures that marginalize or oppress disenfranchised members of the population. Involving the community helps prevent INGOs from inadvertently providing services, building capacity, or teaching advocacy that could have the adverse effect of enabling leaders to be more corrupt or oppressive. ${ }^{21}$

Once the principle of active participation is made explicit in one's understanding of democratic accountability, we can see that this form of accountability supports other processes valuable for democracy, including transparency, freedom of speech, and a more robust civil society. INGOs need to strive toward this form of democratic accountability in order to promote good governance across the globe. Nonetheless, even if all INGOs were able to adhere to these standards of active participation and representation, we must remember that INGOs, as representatives of global civil society, consist of only one part (and a relatively small one at that) of the international relief and development business.

\section{All the Stakeholders}

INGOs, like international corporations, have the power and ability to move in and out of countries, and thus are able to avoid some of the demands for ac-

19. Id. at 596 " If men living in democratic countries had neither the right nor the desire to join together for political ends, they would stand in great danger of losing their independence yet be able to retain what they possessed of wealth and enlightenment for some time to come; whereas if they failed to learn ways of associating with one another in ordinary life, civilization itself would stand in peril.").

20. Ray Jennings, Participatory Development as New Paradigm: The Transition of DevelOPMENT PROFESSIONALISM 6-7 (2000), http://www.usaid.gov/our_work/cross-cutting_programs/ transition_initiatives/pubs/ptdv1000.pdf.

21. See, e.g., Mary B. Anderson, Do No Harm: How Aid Can Support Peace-or War 37-54, 55-66 (1999) (discussing the impact of aid on conflict through resource transfers and the implicit ethical messages); see William Easterly, The White Man's Burden: Why the West's EfForts to Aid the Rest Have Done so Much Ill and so Little Good 135-36 (2006). 
countability that are normally placed on less mobile institutions and organizations. Given their size and scope, INGOs are less powerful than corporations and governments. Understanding this dynamic will provide more insight about the limits of their accountability. Bendell summarizes this dynamic:

Corporations, governments and intergovernmental bodies are much more powerful than NGOs and affect many more people. NGOs do not poison rivers, imprison activists, or declare war. . NGOs do not price public services at a level to make a profit, for example, with the difficulties this often causes for those unable to pay. Neither do NGOs lobby for intergovernmental agreements that will help enhance their profits. As more public services are privatized and more corporations exercise influence at the intergovernmental level, so we should retain a critical focus on their accountability. ${ }^{22}$

Given the variety of players who affect relief and development work, when we consider progress toward good global governance, it is necessary to shine the light not only on INGOs but also on donor governments, intergovernmental organizations, for-profit contractors, the military, and the governments of countries where relief and development work takes place. In this short space, it is impossible to present comprehensive data on all these stakeholders, but the following illustrative data should provide insight into the differences in resources and capacities to create change.

Resources transferred by intergovernmental organizations (such as the United Nations, the World Bank, the International Monetary Fund (IMF), and the European Commission) to states for institutional building and structural adjustment loans dwarf the funds that go to INGOs ${ }^{23}$ and tend to have a relatively poor track record of success. ${ }^{24}$ Results from structural reform loans by the World Bank and

22. BENDELL, supra note 6 , at 75.

23. World Bank commitments totaled $\$ 24.7$ billion in fiscal year 2007. This amount included loans, credits, guarantees, and grants, and was $4 \%$ higher than total lending in fiscal year 2006. See The World Bank, The World Bank Annual Report 2007, at 52-64 (2007). In contrast, in 2004 NGOs received between $\$ 3.7$ billion and $\$ 4.8$ billion. See PETer Walker $\&$ Kevin Pepper, Follow the Money: A Review and Analysis of the State of Humanitarian Funding 5 (2007).

24. For example, "in Chad: less than 1 percent of the money released by the Ministry of Finance for rural health clinics actually reached the clinics." PAUL ColLIER, THE BOTTOM BILLION: WHY THE Poorest Countries Are Failing and What Can Be Done About It 102 (2007). The donor in this case was the European Community and the amount in question was $€ 20$ billion. Id. See Firoze Manji \& Carl O'Coill, The Missionary Position: NGOs and Development in Africa, 78 INT'L AfF. 567 (2002), for a general discussion of this topic. See also David Stuckler et al., International Monetary 
IMF in Latin America, the Eastern Bloc, and Africa show few cases where progress has been made (with the exception of Poland). ${ }^{25}$ In White Man's Burden, William Easterly looks at African countries that received the most structural adjustment loans and concludes:

Indeed, it's a little unnerving that almost all recent cases of collapses into anarchy were preceded by heavy World Bank and IMF involvement. Although I don't think the IMF and the World Bank caused the Ivorian collapse into anarchy, it would be hard to argue that their involvement in the country had a positive long-run effect. ${ }^{26}$

Elsewhere, Easterly explains, quoting Popper, why this approach is flawed: "It is not reasonable to assume that a complete reconstruction of our social system would lead at once to a workable system." ${ }^{27}$ Other observers, though, point out that the Bank's failures are really the responsibility of the member countries, who have set it up to fail. ${ }^{28}$

The increased use of military and for-profit contractors for relief and development work instead of INGOs has added further complexity to this picture. While military spending in the United States is around 5 percent of gross national

Fund Programs and Tuberculosis Outcomes in Post-Communist Countries, PLoS MEDICINE, July 2008, http://medicine.plosjournals.org/perlserv/? request = get-document $\&$ doi $=10.1371 \% 2 \mathrm{Fjournal}$. pmed.0050143 (showing that IMF loans are strongly associated with increases in tuberculosis in 21 former Soviet Union and Eastern European countries).

25. EASTERLY, supra note 21, at 65-69.

26. Id. at 67.

27. Id. at 62. Applying Bertrand Russell's "rotation of nouns" concept helps underscore this point. Imagine a self-appointed team of experts from Niger, Bangladesh, and Cuba deployed to the United States, without invitation, to study the housing and mortgage crisis and implement their recommendations for structural reform with only cursory briefings to Congress. How likely is that to succeed over the short and long-term?

28. Sebastian Mallaby points out that

The bank's leading shareholders will have to recognize that they have set the institution up for failure. They have declared grand development objectives, then done little to support the bank in its efforts to achieve them. They have nobly proclaimed utopian goals, then left the bank to take the blame for not advancing them. Such hypocrisy has set the world's best development institution on a course of steady but preventable decline. If Washington and its allies are serious about managing globalization, this decline must be stopped.

Sebastian Mallaby, Saving the World Bank, Foreign AFF., May/June 2005, at 75, 85. 
product (GNP), official development assistance (ODA) is only .17 percent. ${ }^{29}$ Even when we consider ODA money earmarked only for development, an increasing amount is being channeled through the military. George Packer writes of how the military in Iraq and Afghanistan has taken up many of the responsibilities that used to be the domain of USAID and more traditional aid organizations. ${ }^{30}$ Between 2002 and 2005, USAID's share of ODA decreased from 50 percent to 39 percent, while the Department of Defense's share of ODA increased from 6 percent to 22 percent. ${ }^{31}$ Even within USAID's funds, 80 percent of USAID's direct funding to implementing partners does not go to U.S.-based INGOs. ${ }^{32}$

Even though a large amount of money goes to relief and development through INGOs, it is still only a small percentage of overall funding for relief and development when one considers contributions from governments and intergovernmental organizations through other channels. "In 2005 approximately one-third of the $\$ 8.4$ billion state-donor funding ended up flowing to NGOs directly or via U.N. agencies. ${ }^{33}$ Adding private contributions, the estimate rises to roughly 50 percent. ${ }^{34}$ This estimate is misleading as it includes neither the billions that go directly to states for development work in the form of loans and grants, nor the billions through intergovernmental organizations to for-profit contractors.

A small number of INGOs (CARE, Save the Children, World Vision, Oxfam, Mercy Corps, and others) dominate the field. ${ }^{35}$ On the other hand, the number of local CSOs has grown rapidly because locals understand that partner-

29. Jeffrey Sachs et al., Revamping U.S. Foreign Assistance, Monday Devs., Jan./Feb. 2008, at 6, 7. The European Union (EU) has pledged to achieve .7\% of gross national product (GNP) by 2015. So far, five of the EU countries have reached this a mount.

30. George Packer, Knowing the Enemy: Can Social Scientists Redefine the "War on Terror?," NEW YORKER, Dec. 18, 2006, at 60, 66:

At the counterinsurgency conference in Washington, the tone among the uniformed officers, civilian officials, and various experts was urgent, almost desperate. James Kunder, a former marine and the acting deputy of the U.S. Agency for International Development, pointed out that in Iraq and Afghanistan 'the civilian agencies have received 1.4 per cent of the total money,' whereas classical counterinsurgency doctrine says that eighty per cent of the effort should be nonmilitary.

Id.

31. Walker \& Pepper, supra note 23, at 6.

32. Sam Worthington, People-Centered Development and U.S. Development Assistance, MondaY. DEvs., supra note 29 , at 3,5 .

33. WALKER \& PEPPER, supra note 23, at 5.

34. Id.

35. Id. 
ing with INGOs is a good way to access money, resources and opportunities. ${ }^{36}$ Lindenberg and Bryant observe, "[w]hile figures on NGO growth vary widely, most sources agree that since 1970 the international humanitarian and development nonprofit sector has grown substantially." ${ }^{\prime 37}$ They add that

[w]ithin the developing world, the number of local NGOs with a relief and development focus has also mushroomed. Although estimates of the size of the NGO sector, or the numbers of NGOs in any given country, are often unreliable, one source reports that there are more than 250,000 Southern NGOs. ${ }^{38}$

Local CSOs are often financially dependent on partnerships with INGOs or intergovernmental organizations. For example, in Kenya, CSOs receive more than 90 percent of their operational and capital expenses from abroad. ${ }^{39}$ This level of dependence means, first and foremost, that the local CSOs are accountable to international donors rather than their home communities or local institutions. Many CSOs may pursue projects that are not in fact the top priority within their communities. CSOs will do this as long as foreign donor interest and resources are available. This can delegitimize the CSO in the eyes of the community. In extreme cases, this can result in CSOs being targeted for attack. ${ }^{40}$ However, the more frequent and unfortunate consequence is that the projects only contribute to short-term gains. Once the funds dry up, communities revert back to doing things the way they used to because they were excluded from the project design and implementation. ${ }^{41}$ It is imperative that international donors, intergovernmental organizations, and INGOs develop more genuine partnerships with CSOs and take steps to ensure that their standing in the community remains legitimate.

36. Interview with Aid Workers, Mercy Corps (2008) (on file with author).

37. LiNDENBERG \& BRYANT, supra note 9 , at 3.

38. Id. at 4 (citing Alliance for a Global Community, The NGO Explosion, 7 CommuniCaTions 1 , 1 (1995)); see also Thomas Carroll, Intermediary NGOs: The Supporting Link in Grassroots Development 9-15 (1992); Julie Fisher, Nongovernments: NGOs and the Political DevelOPMENT OF THE THIRD WORLD 4-12 (1998).

39. BENDELL, supra note 6 , at 10-11.

40. Recent attacks have occurred in Afghanistan and Somalia. See Associated Press, 3 Aid Workers Killed in Afghan Attack, INT'L HERALD TRIB., Aug. 13, 2008, available at http://www.iht.com/ articles/ap/2008/08/13/news/A fghan-Violence.php;Somalia: Attackson Aid Workers "Intolerable"Top UN Official, UN Officer for the Coordination of Humanitarian Affairs, INTEGRATED REG'L INFO. NETWORK, July 15, 2008, available at http://www.irinnews.org/report.aspx? ReportId=79255.

41. Interviews with Officials, Ministry of Educ., Maced. (2004) (on file with author). 
The practices of donors will be covered in more detail later in this article. For now, two points about the size and relative power of governmental donors should be noted. First, given that INGOs receive almost half of their funds from government agencies, ${ }^{42}$ it stands to reason that those agencies wield considerable influence over the practices of INGOs; therefore, such donors also bear responsibility for ensuring INGOs are accountable. Second, the competing interests of some donors inhibit the ability of INGOs to work efficiently and effectively. USAID in particular has been subject to considerable criticism for its lack of transparency regarding who receives aid money and for what reasons. As Michael Dobbs wrote in the Washington Post, "Research by Rep. Jim McDermott (D-Wash.) showed that 53 cents of every dollar spent by the Unired States on tackling the AIDS crisis in Africa never left the Washington, D.C., area." ${ }^{43}$ A second example from the same article cites a contract with the for-profit firm Chemonics to promote democracy in Poland. Dobbs points to an analysis that showed that "the bulk of the $\$ 26$ million was spent on aid consultants, many of them Americans, for such things as salaries, airfare, rent, office equipment, cost-of-living allowances, cars and a support staff back in Washington." ${ }^{44}$

The use of for-profit contractors has increased dramatically under the last two administrations. One estimate from 2001 suggested that there was an even split between the use of INGOs and for-profit contractors. ${ }^{45}$ Since the war on terror began, American for-profit contractors have fared even better. In 2003, it was reported that seventy American companies "won up to $\$ 8$ billion in contracts for work in postwar Iraq and Afghanistan over the last two years," ${ }^{46}$ but "[b]ecause of inconsistent and scarce information, the total value of contracts awarded for reconstruction ... may be greater than what is publicly known." 47

While some national governments in the Global South may be powerful (having access to immense resources and the use of armies to further personal interests), ${ }^{48}$ community members may have no ability to access those resources, and may not be able to count on the rule of law to settle disputes fairly and transparently. In such

42. WALKER \& PEPPER, supra note 23, at 5.

43. Michael Dobbs, Aid Abroad is Business Back Home, WASH. Post, Jan. 26, 2001, at Al.

44. Id.

45. Id.

46. Maud Beelman, U.S. Contractors Reap the Windfalls of Post-war Reconstruction, CoRPWATCH, Oct. 30, 2003, www.corpwatch.org/article.php?id =8910.

47. Id.

48. Paul Collier, The Only Answer to the Mugabes of the World May Be a Coup, WASH. POST, June 22,2008 , at B3. 
situations, international donors and INGOs may be perceived as threats because of their potential to unsettle the status quo. INGOs and donors must perform two balancing acts. First, they must work with governments in a way that builds capacity to govern and yet avoids complicity in any abuses. Second, they must work with communities in a way that genuinely empowers and yet does not pose a threat to the government or endanger the lives of those with whom they are working.

Given the data presented in the above section, it is necessary to look closely at the relationships between the different stakeholders and their efforts to improve the accountability of their work.

\section{Relationships Matter: Donors, INGOs, and Communities}

INGOs can certainly do a better job of promoting accountability. The above section sought to illustrate why improving the accountability of other stakeholders matters. ${ }^{49}$ Although it is beyond the scope of this article to explore fully the complex relationships within the sector, we can identify at least ten sets of relationships that must be looked at more closely:

(1) Accountability of donor countries to communities (realized through military stabilization and peace-keeping forces, intergovernmental organizations, for-profit contractors, and INGOs)

(2) Accountability of international organizations (U.N., World Bank, and others) to communities

(3) Accountability of states to provide for and protect their own people in their communities

(4) Accountability of corporations and for-profit contractors to communities

(5) Internal accountability of INGOs

(6) Accountability of INGOs to communities and local CSOs

(7) Accountability of INGOs to the state

(8) Accountability of INGOs to donors

(9) Accountability of INGOs to peers through sharing and learning

(10) Accountability of local CSOs to their community

49. If donors, international organizations, INGOs, and others do not pay attention to improving governance in individual communities, they lose or should lose credibility on the international stage. How can a donor or INGO say that it is working toward good global governance if it causes harm through its work in individual communities around the globe? 
Of these relationships, the donor-INGO relationship, and the accountability of each INGO to its respective community, is most relevant to this article. The following is a first sketch of some of the major considerations within that relationship.

\section{A. Accountability of Donor Countries to Communities}

The accountability of the donor community has not been scrutinized as closely as that of INGOs or CSOs, possibly because they are further removed from project implementation and because INGOs feel they cannot afford to be critical of the very donors upon whom they rely. ${ }^{50}$ Donor countries have various avenues at their disposal. They can work through intergovernmental organizations, engage in unilateral military operations, and, through their development agencies, contract with for-profit contractors or enter into grant agreements with INGOs.

Donors have started to work together to assess their contributions to inefficiencies within the system. ${ }^{51}$ In 2003, the government of Sweden convened a conference for donors that acknowledged that "the real drivers of humanitarian assistance were often far from humanitarian in nature, and that donor governments were a part of the problem." 52 The concept of Good Humanitarian Donorship (GHD) emerged from this conference. ${ }^{53}$ Donors affirmed the need to improve funding by making it

50. Easterly argues that the donors' focus on systemic change (through poverty reduction strategies or grand plans such as the Millennium Development Goals) is flawed because it does not sufficiently take into account the realities on the ground. Funding by project cycle is flawed because of administrative inefficiencies and the creation of incentives for INGOs to promise impossible results. The lack of donor coordination and the number of donors cause inefficiencies in proposal development, reporting, and disincentives to share information. Donors also do not set priorities based on need, but on political, historical, and economic factors. Additionally, funding cycles are often too short; changing knowledge, attitudes, and practices requires longer interventions. See EASTERLY, supra note 25, at 195-97.

51. Different funders, including governments, intergovernmental organizations, and corporations have different priorities, criteria for funding, timelines, and approaches to development, which makes coordination difficult.

52. Ian Smillie, Distant Obligations: Disorder and Reform in the Response to Humanitarian Emergencies 10 (Apr. 2007) (unpublished manuscript, on file with author).

53. See Good Humanitarian Donorship, http://www.goodhumanitariandonorship.org/ (last visited Sept. 19, 2008) (highlighting efforts to improve performance of relief efforts including the Global Humanitarian Platform (GHP), which has brought together the following three large groupings of actors: (1) INGOs and CSOs, (2) Red Cross/Red Crescent agencies, and (3) U.N. and other intergovernmental organizations); see also Elizabeth Ferris, The Global Humanitarian Platform: Opportunity for NGOs?, ForCEd MigRaTION REv., Dec. 2007, at 6, available at http://www.fmreview.org/FMR pdfs/FMR29/6-8.pdf (stating the aim of the GHP platform is to make relief operations more effective while also highlighting the problem of who will coordinate the coordinators). 
more flexible, ${ }^{54}$ to provide assistance according to need, ${ }^{55}$ to improve their own accountability, and to promote learning. ${ }^{56}$ Donors also affirmed the need for beneficiary involvement to "the greatest possible extent" in all aspects and phases of response. ${ }^{57}$ The rhetoric needs to be informed by the reality on the ground. Despite some improvements, there is a long way to go. As Smillie points out,

Iraq and Afghanistan, the two largest recipients of humanitarian assistance, are almost completely absent from GHD discourse. The poor response to the appeals for Guyana, Niger and Liberia described in this paper happened well after the GHD has been launched, as did the chaos surrounding the Asian tsunami. ${ }^{58}$

Collier writes about the immense challenges in countries where there is extreme poverty, shoddy institutional structures, and economic and military instability. It is these places where the need for constructive intervention is greatest. ${ }^{59}$ While the track record of the international community, writ large, certainly could be improved, Collier puts the onus for change on INGOs:

Aid agencies should become increasingly concentrated in the most difficult environments. That means that they will need to accept more risk, and so a higher rate of failure. They should compensate by increasing their project supervision, which means higher administrative overheads .... At present the powerful force of public opinion is driving agencies in precisely the opposite direction. They cannot afford failure. They have to be lean with low administrative expenses. ${ }^{60}$

While it is true that more and better project supervision would improve INGOs' effectiveness, the real constraint is not due to public opinion, as Collier

54. Int'l Meeting on Good Humanitarian Donorship, Principles and Good Practice of Humanitarian Donorship, princ. 12 (June 17, 2003), available at http://www.goodhumanitariandonorship.org/ backgroundl.asp.

55. Id. princ. 2.

56. Id. princs. 21-23.

57. Sara Davidson et al., Accountability to Affected Populations, in NGO ImPaCt INITIATIVE 13, 13 (Oct. 2006), available at https://www.redcross.org/news/in/tsunamis/ngoreport.pdf.

58. Smillie, supra note 52, at 13.

59. COLLIER, supra note 24 , at $8-12$.

60. Id. at 184 . 
suggests, but, rather to donors (both state agencies and private foundations) that determine which INGO to fund and oblige INGOs to follow the donors' funding parameters. Thus, Collier's call for INGOs to change cannot be met until donors provide the flexibility for INGOs (or for-profits) to budget for longer interventions, more support from headquarters, and more accountability measures.

Inadvertently, some standard practices of donors end up compromising the activities that INGOs and their local partners undertake to achieve proposal objectives. INGOs are often expected to demonstrate dramatic and systemic results with relatively small inputs (and little ability to leverage resources from other, much larger players). It is unrealistic to expect INGOs to achieve societal change with a fraction of the amount that is available to intergovernmental organizations or the military or corporations, especially when these other actors can make it more difficult for INGOs to implement projects on community and national levels. Additionally, the short time frames for most donor-funded projects encourage INGOs to focus on outputs rather than impact and force INGOs to give short shrift to activities that take longer than the time allotted but would be more likely to lead to sustainable change. Donor requirements often limit the flexibility an INGO might need in order to best achieve proposal objectives. The world in which INGOs operate is far from static; in such an environment, political, military, and economic circumstances change and often necessitate significant re-shaping of project activities.

At times, donors will significantly change priorities with little notice, which not only creates difficulties for INGOs, but also more importantly, can have a disruptive effect on the affected community, leading to dependence on the donor. While it is understandable that donor priorities may also change, more attention should be given to the manner in which such changes are carried out and focused on efforts to mitigate the negative impact of those changes on communities.

Donors and INGOs would benefit from the introduction of measures encouraging greater cooperation and an increased focus by INGOs on people and the community instead of projects. ${ }^{61}$ Some European countries have promoted a partnership model in which donors provide unrestricted funds to INGOs that

61. Packing projects into specific boxes based on sectors, such as a health project or a micro-finance project, may make sense to donors and INGOs because it facilitates staffing decisions. However, communities and INGOs would probably both prefer unrestricted funding that could be directed and managed according to needs and opportunities as they arise. Instead of allocating funds to specific sectors, a process that assigns funding based on geography would make more sense, since this is how our lives are structured. Resources would go to the region or community that needs it, thus making it easier for donors to pool resources, unify reporting procedures, and conduct other necessary tasks. 
have a proven track record and a shared set of values. ${ }^{62}$ This approach allows INGOs to base programming decisions on the needs they see in and from the communities, rather than on priorities predetermined by donors. Such innovations have proven successful and should be replicated. ${ }^{63}$

\section{B. Facilitating Donor Learning from INGOs}

Some donors have shown that they should and can learn from INGOs and can foster peer learning among INGOs. The Gates Foundation, for instance, has provided funds for the Emergency Capacity Building project, a collaborative effort by CARE, Catholic Relief Services, International Rescue Committee, Mercy Corps, Oxfam GB, Save the Children, and World Vision. ${ }^{64}$ These seven organizations have agreed to share information about each of their "best practices." ${ }^{\prime 5}$ One product of that collaboration is the modestly named but very useful Good Enough Guide, which outlines elements of accountability and impact measurement in emergency responses and includes numerous practical tools for field workers to use. ${ }^{66}$

INGOs also have the ability to influence donors through global policy advocacy. INGOs can organize or take part in any number of campaigns: Millennium Development Goals, ${ }^{67}$ climate change, debt relief, ending practice of female genital mutilation, and other campaigns. The richest and most influential INGOs, though, are from the West and thus often end up speaking on behalf of people in the Global South. Ultimately, the challenge should be to find ways, as Bendell suggests, "to increase Southern capacity and legitimacy within international are-

62. In Sweden, these are called "cooperation partners." SIDA AT WORK: A GUIDE TO PrINCIPLES, PRocedures AND Working Methods 7 (Nov. 2005), http://www.sida.se/shared/jsp/download. jsp? $f=$ SIDA286len_Sida $+a t+W o r k+2005+$ Guide_web.pdf $\& a=2857$. In Finland they are known as "partner organizations." Minister for Foreign Affairs of Finland, Support for Partner Organizations, http://formin.finland.fi/public/default.aspx ? nodeid $=15436 \&$ contentlan $=2 \&$ culture $=$ en-US (last visited Sept. 28, 2008).

63. Interview with Sunoor Verma, Head of Dev. \& Reg'l Mgmt., European Ctr. for Minority Issues, Maced. (Aug. 2004).

64. Emergency Capacity Building. Project, The Good Enough Guide: Impact MeasureMENT AND ACCOUNTABILITY IN EMERGENCIES, at iii (2007), http://www.globalpolicy.org/ngos/ aid/2007/0209goodenough.pdf.

65. Emergency Capacity Building Project, http://www.ecbproject.org/ (last visited Sept. 19, 2008).

66. See generally EmERGency CAPACity Bullding Project, supra note 64.

67. See United Nations Millennium Development Goals, http://www.un.org/milleniumgoals/ (last visited Sept. 19, 2008). 
nas of power and decision making, thereby breaking down the hierarchical division of labour that currently characterizes international advocacy."

Some of the issues that are taken up by INGOs are more complicated than they first appear. What seems like a good idea from the perspective of people in the United States may cause more problems in another country. ${ }^{69}$ INGOs would do well to develop creative ways to bridge the chasms between ordinary civilians from the Global South and those in international decision-making positions.

\section{Constraints on Donors' Ability to Act}

Individual governments' development agencies and intergovernmental organizations need to be held more accountable for decisions they make regarding how they set priorities (and from whom they collect information to make those decisions), what regions they fund, how they get funds there, and whom they fund and for what activities. The development agencies obviously follow policy set by their governments. That said, each agency has, to varying degrees, autonomy to make decisions at the operational level. Likewise, although intergovernmental organizations have some autonomy to set procedures, allocate funds, and direct humanitarian and development efforts, they are heavily influence by government policies.

\section{Donor Relations with Other Actors-Military, Intergovernmental Organizations, and Corporations}

It is beyond the scope of this article to cover these topics, except to emphasize the importance these other actors play in the field of international relief and development (as mentioned in the above section discussing the size of the stakeholders). While a critique of the donor-INGO relationship is certainly possible without looking at these other stakeholders, more scholarship is needed on the impact these other actors have on the efficiency and effectiveness of international relief and development.

Bendell, writing about the nonprofit sector, observes that there are many im-

68. BENDELL, supra note 6 , at 25.

69. "Fair trade" is one example of a practice that is widely seen in progressive circles as worthy of support. Although there may be a small rise in worker pay, Collier observes that workers are still trapped in the production of these basic commodities, whereas what needs to happen in the communities is the diversification of production and manufacturing in order to eliminate poverty. COLLIER, supra note 24, at 163 . Moreover, given the cost of certification, fair trade may disproportionately benefit larger and wealthier producers, exacerbating income inequalities locally. 
portant nonprofit actors, not to mention business, military, and other interests that influence progress within a country or a community:

The recent attention of policy makers, secretariats, lobbyists, practitioners and media pundits, along with academics in development studies and political science has focused on a very small segment of the voluntary sector: those organizations that choose the acronym NGO. If we are interested in democracy then there is little justification for this, because most organizations which are neither non-governmental nor for-profit do not often call themselves NGOs and have much more power and influence in society than those that do. ${ }^{70}$

This is not to say that INGOs are without fault. The following section discusses some steps that INGOs are taking to improve their accountability.

\section{E. Internal Accountability of INGOs and INGO Accountability to Communities}

INGOs have been criticized for their questionable fund-raising efforts; lack of transparency with regard to the use of funds; imposition of their own interests and agendas on communities, or the perception of such imposition; reliance on government funds, which limits the ability of NGOs to objectively monitor the functioning of the state; and finally, in extreme cases, misuse and abuse of aid. ${ }^{71}$ Mark Moore and William Ryan categorize four general social concerns about nonprofit performance: "diversion of assets to private benefit, waste of resources in organizational operations, ineffectiveness of organizational methods in achieving desired social results, and imperfect judgment in fitting missions to important social problems." 72 Anderson points out that it is nonetheless incorrect to conclude that resources for aid should not be disbursed because of these inefficiencies.

Many people criticize international assistance, accurately citing examples of ways in which international aid has done harm rather

70. See BENDELL, supra note 6, at 76 (referring to religious organizations, educational organizations, professional associations, and labor organizations).

71. See generally id. (addressing concerns about the role and accountability of NGOs).

72. Mark H. Moore \& William P. Ryan, A Framework for Analyzing Nonprofit Governance and Accountability Policies and Strategies 7-8 (Hauser Ctr. for Nonprofit Org., Working Paper No. 33.3, 2006), available at http://www.hks.harvard.edu/hauser/PDF_XLS/workingpapers/workingpaper_ 33.3.pdf. 
than good. We note such examples, but we do not condemn aid for its failures. It is a moral and logical fallacy to conclude that because aid can do harm, a decision not to give aid would do no harm. In reality, a decision to withhold aid from people in need would have unconscionable negative ramifications. ${ }^{73}$

It is clear that INGOs need to undertake measures to ensure they are accountable. Most large INGOs have a variety of mechanisms to encourage staff development and education, to evaluate their own work, and to ensure activities are linked to their missions. They have devised standards to ensure good governance and accountability of program operations and have set up mechanisms to adhere to those standards. ${ }^{74}$

More improvements can be made. The Post-Tsunami UN-NGO Impact Initiative identified four "dimensions of accountability": transparency, participation, evaluation, and complaints and response mechanisms. ${ }^{75}$ Steps to improve INGO accountability along each of these dimensions can be taken with respect to communities as well as local partners.

Greater transparency in all aspects of INGO work would help communities to distinguish one INGO from another, and would provide more knowledge about who is using resources wisely, enabling communities to engage with INGOs on more equal footing.

While many large INGOs have organizational learning departments or initiatives to further design, monitoring and evaluation techniques, ${ }^{76}$ these efforts tend to be relatively new and are often under-funded or under-utilized. Some INGOs may have ad hoc working groups to ensure participation of traditionally marginalized groups (for instance, women, ethnic or religious minorities, or persons with disabilities) or to research best practices in particular fields or sectors. These efforts for greater inclusivity and accountability need to be supported by the highest level of management in order to change organizational culture. Oth-

73. ANDERSON, supra note 21 , at 2 .

74. In the requests for proposals and applications, the large donors (USAID, EC, and others) rightly require INGOs to demonstrate their ability to evaluate the outputs and impact of all proposed projects. See Monica Blagescu et al., Evaluation in International Organisations: Background Research for Evaluation Dimension, Sept. 2005, at 11-18, http://www.oneworldtrust.org/documents/Evaluations\%20 Sector\%20paper.pdf (explaining some of the challenges of evaluations of proposed projects).

75. Davidson, supra note 57, at 3.

76. The development of these practices in several of the larger INGOs are tracked in LINDENBERG \& BRYANT, supra note 9, at 221-34. 
erwise staff will see these initiatives as additional burdens and will be less likely to pursue them.

It is imperative for headquarters-led initiatives to filter down to the field offices as well and for field staff to have the ability to inform headquarters of changes in circumstances and influence policies. Too often senior-level field officers are white, male expatriates. INGOs would benefit from a more representative field staff, which would would strengthen the links to the communities and increase the flow and accuracy of information.

Efforts, such as the Emergency Capacity Building project or the Listening Project, show that INGOs are undertaking measures to ensure adherence to these dimensions in their relationships with communities. Accountability standards can be developed through various initiatives to help ensure that INGOs work with community members in ways that protect their well-being, respect their potential, and foster the development that the community is pursuing. Standards include the Sphere Guide, ${ }^{77}$ which sets guidelines for organizations involved in humanitarian responses, and codes of principles and conduct developed by organizations such as the Red Cross, InterAction, and People in Aid. In addition, frameworks such as "Do No Harm" help organizations analyze contexts and design appropriate interventions. ${ }^{78}$ Some tools are used to map power dynamics and relationships among stakeholders; others provide guidance on increasing inclusion of groups, such as women or persons with disabilities. ${ }^{79}$ While standards, frameworks, and tools exist in abundance, more guidance and collaboration is needed in order to operationalize and harmonize them.

Long-term progress depends on INGOs' ability to build capacity of local partner CSOs and institutions both in humanitarian response and in longer term development. Too often INGOs end up making decisions that should have and could have been made locally.

77. The Sphere Project, Humanitarian Charter and Minimum Standards in Disaster ReSPONSE (2004), http://www.sphereproject.org/index.php? option =content\&task =view\&id $=27 \&$ Ite mid $=84$.

78. Collaborative Learning Projects, http://www.cdainc.com/cdawww/project_profile. php? pid $=$ DNH \& pname $=$ Do\%20No\%20Harm (last visited Nov. 18, 2008).

79. For example, a gender audit tool is available through the InterAction website, http://www.i nteraction.org/caw/services.html (last visited Sept. 19, 2008). Many resources on gender can be found at the United Nations International Research and Training Institute for the Advancement of Women, http://www.un-instraw.org/ (last visited Sept. 19, 2008). Tools on disability inclusion are available through Mobility International, Disabled Peoples' International, and other resources. 


\section{F. INGO Accountability to States}

INGOs need to ensure proper measures are in place to ensure that staff members behave with the proper degree of professionalism and respect for local and national laws, customs, traditions, and culture. There are too many accounts of reckless behavior that put people in harm's way and damaged the effectiveness of INGO work. ${ }^{80}$

In addition to the mission of facilitating community empowerment, INGOs also need to work with state and local institutions as much as possible, as these structures will continue to exist after the INGOs' departure. A more robust effort to involve state and community actors in project design would be one of the many ways to improve accountability to the INGO host country.

\section{G. INGO Accountability to Peers through Sharing and Learning}

INGOs make use of various opportunities to share information, exchange best practices, and support each other's work..$^{81}$ The goal of these activities is to improve the efficiency of programs and their impact on the ground. For example, InterAction, a network of over 165 U.S.-based INGOs, advocates to the U.S. government to secure more funds for relief and development efforts, works to improve NGO performance through the development and sharing of tools and resources, and encourages cooperation and networking along common interests. ${ }^{82}$

Other initiatives include the Human Accountability Project (HAP) and the Active Learning Network for Accountability and Performance in Humanitarian Action (ALNAP) ${ }^{83}$ Both ALNAP and HAP focus on improving accountability to beneficiaries, implementing measures to enhance local capacities, and developing mechanisms to better the lives of affected populations. A project spearheaded by the Collaborative for Development Action deserves special mention. Their Listening

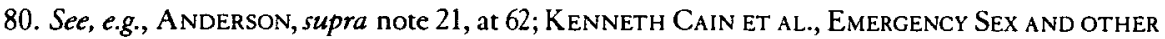
Desperate Measures (2004).

81. See e.g., ALNAP, http://www.alnap.org/(last visited Sept. 28, 2008); InterAction, http://ww w.interaction.org/about/index.html (last visited Sept. 28, 2008); ReliefWeb, http://www.reliefweb.int (last visited Sept. 28, 2008).

82. See InterAction, supra note 81.

83. HAP was launched by thirteen international emergency relief and development organizations connected to the InterAction network. ALNAP achieves its goal of improving education, accountability, and performance through sharing lessons, identifying common problems, and building consensus on approaches. 
Project takes the commitment to accountability one step further by interviewing people in communities that receive aid, as well as the people in communities and neighboring communities who have not benefited from relief and development assistance. ${ }^{84}$ This activity is premised on the understanding that foreign organizations "must both listen carefully to the wise judgments of the people in those societies about how these [assistance] efforts have gone and be accountable to them." 85 Their initial findings show that the organization structures (such as staffing and decisionmaking authority) and approach (treating locals as beneficiaries to be assisted rather than as subjects who have an opinion on what should be done and why) have limited INGOs' ability to listen to locals. "The systems of international assistance bias the ways that agencies and aid workers listen and do not listen, what they listen to, where and when they listen, and to whom they listen." ${ }^{.86}$

Given the competitive nature of the relief and development field, INGOs may need donors, like the Gates Foundation (through the Emergency Capacity Building project), to incentivize cooperation so that they can go beyond mere sharing of what has been done. To encourage good governance, INGOs must seek engagement from communities and local institutions during design and implementation, be empowered by donors to make necessary adjustments as needed, and place real value on evaluation. Easterly has called for the creation of an independent evaluation fund into which INGOs would have to pay. ${ }^{87}$ Evaluators supported by that fund would undertake process and impact evaluations of any INGO, would obtain input from beneficiaries, and then would report back to a wider INGO forum with the results. ${ }^{88}$

\section{Conclusion}

INGOs have broad missions which have, as a common element, the goal of stabilizing and strengthening the communities in which they work. This goal can be achieved through disaster response and other humanitarian relief, by providing tools to improve the ability of locals to govern, and by improving local civil society's ability to hold local government accountable-the best way to render

84. See generally Collaborative Learning Projects, http://www.cdainc.com/cdawww/

project_profile.php? pid $=$ LISTEN\&pname $=$ Listening\%20Project (last visited Nov. 18, 2008) (providing an overview of the Listening Project).

85. Mary Anderson \& Dayna Brown, Listening to Improve Accountability, MondaY Devs., Dec. 2007 , at $10,10$.

86. Id. (emphasis omitted).

87. EASTERLY, supra note 21 , at 370.

88. Id. 
further international interventions unnecessary. INGOs have the ability to act globally, but they need to think locally about the consequences of their actions and devise better methods for facilitating democratic accountability at all levelswithin their own organizations, toward the country and communities in which they work, and with their local partners. INGOs do not act alone, however, and do not have as much power, as defined by resources, time and money, as other stakeholders such as donor countries, international corporations, intergovernmental organizations, and host countries. Collier observes that
Aid, however, is not the only answer to the problems of the bottom billion. In recent years it has probably been overemphasized, partly because it ... fits so comfortably into a moral universe organized around the principles of $\sin$ and expiation .... Aid does have seri- ous problems, and more especially serious limitations. Alone it will not be sufficient to turn the societies of the bottom billion around. But it is part of the solution rather than part of the problem. The challenge is to complement it with other actions. ${ }^{89}$

Relief and development work is a means to an end; it is a tool to help reconstruct societies that have failed or are in danger of failing. By highlighting some of the efforts being undertaken by INGOs, as well as by donors and intergovernmental organizations, this article has endeavored to show their contributions toward global good governance. The main challenge for all stakeholders, not just INGOs, is to improve their accountability to the communities in need. This would constitute a fundamental and significant change in the approach and practice of humanitarian relief and development work, but this call is not a new one. In their report, Firoze Manji and Carl O'Coill cite a statement from an African NGO to the U.N. General Assembly in 1986:

We encourage Northern and international NGOs to recognise the linkages of many policies of their governments, corporations and multilateral institutions which their governments heavily influence and which adversely affect the quality of life and political and economic independence of African countries. ${ }^{90}$

89. COLLIER, supra note 24 , at 123.

90. Manji \& O'Coill, supra note 24, at 582 (quoting Kingston Kajese, An Agenda of Future Tasks for International and Indigenous NGOs: Views from the South, 15 WORLD DEv. (Supp.) 79, 83-84 (1987)). 
While INGOs and the aid agencies of different donor governments are making valuable contributions to good global governance, the last twenty years have proven that they cannot do it alone. All of the various international stakeholders must listen closely to the voices from the Global South, undertake activities in furtherance of the interests of community members while adhering to international law, and support, with respect and humility, processes of locally-led development. 


\section{Indiana University Press/Journals}

\section{Race/Ethnicity Multidisciplinary Global Contexts}

A peer-reviewed journal jointly produced through The Kirwin Institute for the Study of Race and Ethnicity and the Office of Minority Affairs at The Ohio State University

PUBLISHEO SEMIANNUALIY eISSN 1935-8562 pISSN 1935-8644

800-842-6796

812-855-8817

http://inscribe.iupress.org Available in electronic, combined electronic \& print, and print formats

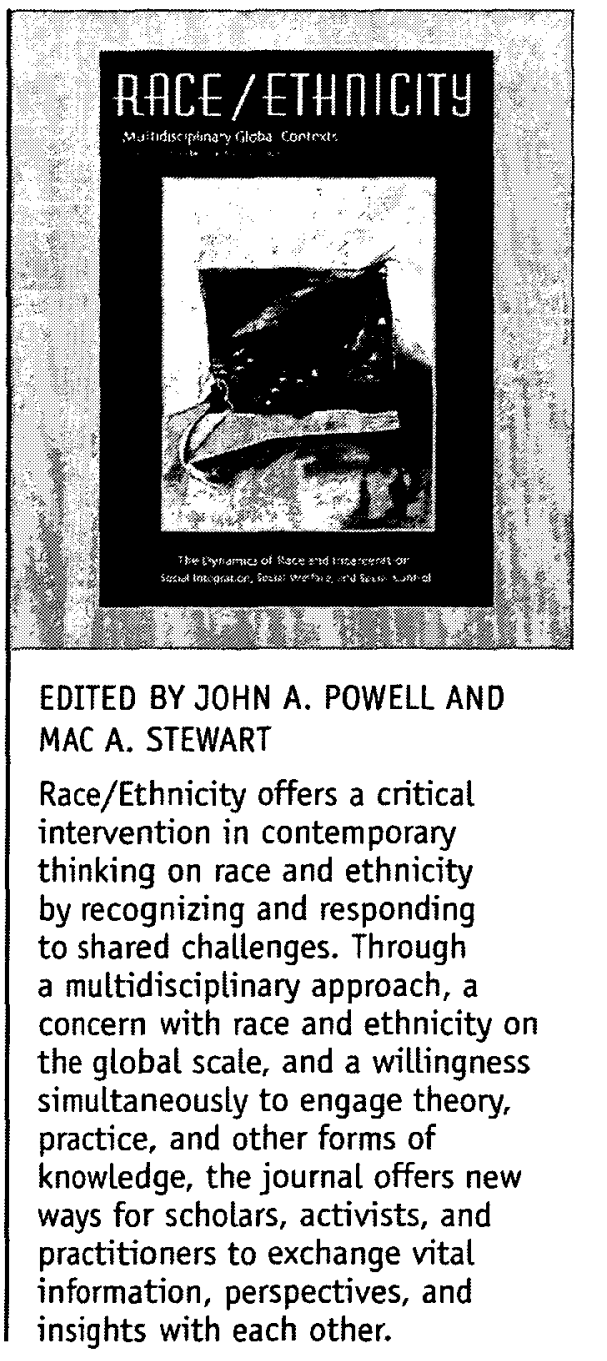

\section{】T INDIANA UNIVERSITY PRESS}

601 North Morton Street, Bloomington, Indiana 47404-3797 USA 